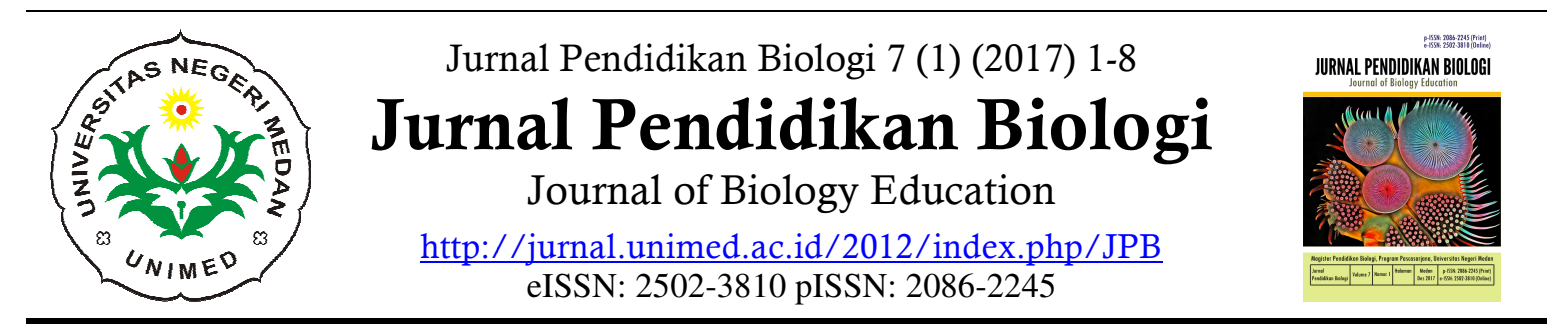

\title{
Pengaruh Media Pembelajaran dalam Tataran Strategi Pembelajaran TPS (Think- Pair - Share) Terhadap Retensi Belajar Siswa SMA Mitra Inalum
}

\author{
Irwansyah* \\ Fakultas Keguruan dan Ilmu Pendidikan, Universitas Quality \\ *Korespondensi: iirwan135@gmail.com
}

\begin{abstract}
This research was aimed to know The best learning strategy between the cooperative learning strategy type TPS with animation media, cooperative learning strategy type TPS with static picture media, and conventional learning strategy to the memory retency of XI grade students in State Senior High School Mitra Inalum. This research was conducted with quasi experiment methods with three classes which sample randomly, XI IA.1 class with cooperative learning strategy type TPS with animation media; XI IA. 2 class with , cooperative learning strategy type TPS with static picture media, and XI IA. 3 class with conventional learning strategy. Instrument in this research used achievement test in the form of 50 multiple-choice questions that have been tested for validity, reliability, dicrimination power, and difficulty level. Student's retency memory can be gathered from the achievement test after 21 days sub matter is done finished. The techique of analysis used analysis of covarians with SPSS 17.0 for Windows. The result of this research and test shows the best learning strategy to get student memory retency is cooperative learning strategy type TPS with static picture media, continued by cooperative learning strategy type TPS with animation media, and then with conventional learning strategy. There are differences between memory retency XI grade students in State Senior High School of Mitra Inalum thay by used the cooperative learning strategy type TPS with animation media, cooperative learning strategy type TPS with static picture media, and conventional learning strategy (Sig. $=0.03<0.05$ ).
\end{abstract}

Keyword: Think Pair Share, Media Animasi, Media Gambar Diam, Retensi Memori

\section{PENDAHULUAN}

Para pengajar seringkali kesulitan dalam mengajarkan proses-proses seluler dan molekuler yang bersifat abstrak. Keterbatasan sumber-sumber belajar, dan fasilitas laboratorium yang tidak memadai, banyaknya peserta dalam satu rombongan belajar, waktu yang tersedia tidak mencukupi menyebabkan penyampaian materi hanya berdasarkan buku teks yang dipakai dalam pembelajaran. Materi dan metode pembelajaran yang cenderung monoton sehingga menyebabkan proses belajar mengajar kurang menarik perhatian siswa (Prayitno \& Manullang, 2010).

Faktor-faktor yang menyebabkan kualitas pendidikan masih rendah antara lain kurangnya pengakuan dan penghargaan terhadap perbedaan individu siswa pembelajaran yang kurang dapat menumbuhkan kesadaran akan makna belajar, dan pembelajaran yang masih bersifat teacher centered (Marpaung, 2001). Penggunaan media pembelajaran yang tidak efektif, dimana media yang 
digunakan hanya dilihat dari sudut kepentingan guru, contohnya, karena guru kurang menguasai bahan pelajaran maka media tertentu digunakan, bukan dari sudut kebutuhan, minat, dan kondisi siswa (Sanjaya, 2008). Guru masih kurang memperhatikan pengalaman siswa dalam lingkungannya untuk dapat diangkat dalam proses pembelajaran, kurang memperhatikan penguatan konsep dalam proses belajarnya, serta kurang memperhatikan perolehan belajar mereka selama proses pembelajarannya (Wirahayu, dkk, 2007).

Masalah yang sama dapat terlihat pada hasil belajar biologi di SMAS Mitra Inalum. SMAS Mitra Inalum merupakan salah satu Sekolah Menengah Atas di Kota Medan yang telah berstatus Rintisan Sekolah Standar Nasional (RSSN) memiliki jumlah kelas XI sebanyak 9 kelas. Khusus untuk kelas IPA sebanyak 6 kelas. Pembelajaran biologi sebagian besar sudah menggunakan Liquid Crystal Display (LCD) sehingga membantu dalam penyampaian informasi berbentuk audio visual kepada siswa. Rendahnya hasil belajar kognitif, dapat dilihat berdasarkan nilai rata-rata hasil semester ganjil dari 3 tahun terakhir dimana didapati nilai ujian semester biologi tergolong rendah karena Kriteria Ketuntasan Minimal (KKM) mencapai 64 - 65 dari tahun pembelajaran 2011/2012 sampai dengan 2012/2013.

Hal ini membuktikan bahwa sejumlah informasi tidak bertahan lama dalam ingatan siswa. Masih rendahnya kualitas belajar siswa dapat diketahui dari indikator kualitas proses dan hasil belajar. Kualitas proses pembelajaran dapat diamati dari bagaimana aktivitas siswa, interaksi gurusiswa, interaksi antar siswa, dan motivasi belajar siswa. Sedangkan kualitas hasil belajar dapat diamati dari prestasi belajar dan ketuntasan belajar siswa.

Strategi pembelajaran kooperatif secara sadar menciptakan interaksi yang saling asah sehingga sumber belajar bagi siswa bukan hanya guru dan buku ajar tetapi juga sesama siswa (Nurhadi \& Senduk, 2003). Adapun berbagai elemen dalam pembelajaran kooperatif adanya saling ketergantungan positif; interaksi tatap muka, akuntabilitas individual, dan ketrampilan untuk menjalin hubungan antar pribadi atau keterampilan sosial yang sengaja diajarkan (Abdurrahman \& Bintoro, 2000).

Armstrong (2007) melaporkan bahwa penerapan pembelajaran kooperatif secara signifikan dapat meningkatkan hasil belajar siswa. Hal ini terjadi karena banyak melibatkan interaksi antar siswa serta didasarkan pada kerja tim yang heterogen, sehingga individu harus memiliki sikap tanggung jawab, berkomunikasi, mengevaluasi dan saling ketergantungan positif dengan sesama anggota kelompok. Kartolo (2010) melaporkan bahwa terdapat interaksi kemampuan awal tinggi dan rendah dengan strategi pembelajaran kooperatif tipe TPS dan TGT terhadap prestasi belajar siswa dan terdapat interaksi antara strategi pembelajaran kooperatif tipe TPS dan TGT dengan aktivitas belajar siswa terhadap prestasi belajar siswa.

Arsyad (2005) berpendapat agar proses belajar mengajar dapat berhasil dengan baik, sebaiknya siswa diajak untuk memanfaatkan semua alat inderanya. Arsyad (2005) menyatakan bahwa belajar melalui stimulus gambar atau visual membuahkan hasil belajar yang lebih baik untuk tugas-tugas seperti mengingat dan mengenali kembali. Pelibatan berbagai organ tubuh mulai telinga (audio), mata (visual), dan tangan (kinetik) membuat informasi lebih mudah di mengerti (Arsyad, 2005). DePorter (2000) mengungkapkan manusia dapat menyerap suatu materi sebanyak 50\% dari apa yang didengar dan dilihat (audio visual), sedangkan dari yang dilihatnya hanya $30 \%$ (visual), dari yang didengarnya hanya $20 \%$ (audio), dan dari yang dibaca hanya $10 \%$.

Kemampuan menghadirkan objekobjek yang sebenarnya tidak ada secara fisik atau diistilahkan dengan imagery. Menurut Matlin (1984) objek-objek yang tidak nyata tidak selalu dapat dihadirkan selayaknya representasi dunia nyata. Secara kognitif pembelajaran dengan menggunakan mental imagery akan meningkatkan retensi siswa dalam 
mengingat materi-materi pelajaran yang ada. Biologi merupakan subjek visual yang sering mengandung urutan proses dinamis yang kompleks dan konsep-konsep abstrak, maka alat visualisasi yang digunakan adalah animasi dan gambar diam (McClean et al., 2005; Lin et al, 2006; O’Day, 2007).

Beberapa penelitian yang berkaitan adalah McClean et al,.(2005) melakukan penelitian dengan kelompok kecil yang melihat animasi tiga dimensi pada topik sintesis protein pada kombinasi yang bervariasi pada pembelajaran individu dan ceramah dibandingkan pembelajaran dengan ceramah tanpa menggunakan animasi. Pada setiap kasus, kelompok yang melihat animasi memiliki nilai yang lebih tinggi secara signifikan pada tes lanjutan dari pada kelompok yang tidak melihatnya Rieber (1990) menunjukkan bahwa dengan menggunakan animasi untuk mengkomunikasikan gagasan dan proses yang berubah di akhir, akan mengurangi abstraksi yang berhubungan dengan transisi temporal dari proses tersebut. Paivio (1991) menyatakan animasi membantu dalam memperpanjang aspek visual dari memori jangka panjang.

McClean et al. (2005) melalui penelitian lebih lanjut menunjukkan bahwa dengan menggunakan alat visual yang dirancang dengan baik, pebelajar dapat mencerna sejumlah besar informasi dalam waktu relatif singkat dan mengkonstruksi visualisasi dari suatu proses. Penelitian Koroghlanian dan Klein (2004) yang ditujukan untuk mengetahui dampak audio dan animasi dalam pengajaran multimedia pada konsep abstrak mengindikasikan bahwa kemampuan spasial secara signifikan berkaitan dengan prestasi belajar dan sikap. O'Day (2006) menjelaskan bahwa animasi lebih efektif untuk menghadirkan pembelajaran yang berkualitas.

Berdasarkan fakta di atas, maka penulis berpendapat bahwa untuk mengatasi masalah yang dihadapi dalam pembelajaran biologi adalah memperhatikan faktor - faktor yang mempengaruhi hasil belajar siswa agar diperoleh pembelajaran yang efektif, mampu menguatkan retensi memori mereka akan sejumlah informasi yang akan berdampak pada hasil belajar kognitifnya.. Pengaruh penggunaan strategi pembelajaran kooperatif tipe TPS dengan menggunakan media animasi dan gambar diam akan dilakukan pada materi struktur dan fungsi sel. Hal ini dilakukan untuk memperoleh fakta yang jelas mengenai perbedaan retensi memori siswa dari sejumlah informasi yang saling berbeda.

Dari uraian di atas, maka penelitian ini ingin menemukan strategi pembelajaran yang terbaik dari strategi pembelajaran kooperatif tipe TPS melalui media animasi, strategi pembelajaran kooperatif tipe TPS melalui media gambar diam, dan strategi pembelajaran konvensional terhadap retensi memori siswa kelas XI SMAS Mitra Inalum.

Keberhasilan siswa memahami suatu konsep yang diajarkan oleh guru, ditentukan oleh kemampuan menyimpan abstraksi konsep dalam struktur kognitifnya. Kemampuan menyimpan abstraksi konsep dalam struktur kognitif diukur dengan retensi atau ingatan. Kemampuan menerima, menyimpan, dan menimbulkan kembali dikenal dengan isitilah encoding (pengkodean terhadap apa yang dipersepsi, yaitu proses menerima), storage (penyimpanan), retrieval (pemulihan kembali terhadap apa yang telah dialami atau dipelajari sebelumnya). O'Day (2007) menjelaskan bahwa memori akan mengalami kemunduran (lupa) spesifik seiring dengan jalannya waktu. Ide ini aslinya ditemukan oleh Hermann Ebbinghaus pada tahun 1885, kurva lupa merupakan peralatan umum dari inti peringatan masa lalu. Kurva kelupaan atau kemunduran daya ingat seiring berjalannya waktu intinya adalah suatu logaritma dengan fase cepat pada awal kelupaan yang diikui dengan fase progresif yang lebih lambat.

Pada proses pembelajaran yang tidak disertai dengan pengulangan, paling banyak siswa akan mengingat sebanyak $25 \%$ dari apa yang dipelajari setelah satu minggu dan akan terus berkurang hingga 
$21 \%$ setelah $2-4$ minggu setelah pembelajaran. Dengan demikian perlu diupayakan pembelajaran yang bermakna bagi siswa. Pembelajaran yang banyak melibatkan panca indra dalam proses berpikir dapat memungkinkan pembelajaran menjadi lebih bermakna, sehingga dengan demikian memungkinkan kuatnya retensi siswa terhadap konsepkonsep yang diajarkan. Untuk memenuhi hal tersebut guru sedapat mungkin melibatkan siswa dalam proses pembelajaran, salah satunya adalah dengan memberikan pertanyaan untuk memacu keterlibatan berpikir siswa sehingga siswa dapat menggunakan dan mengaitkan konsep-konsep yang telah dimilikinya.

Penggunaan media yang tepat dapat meningkatkan retensi memori siswa, karena media mampu memvisualisasikan materi yang selama ini sulit untuk diterangkan apabila dengan penjelasan atau alat peraga yang konvensional. Visualisasi yang disajikan melalui suatu media, memungkinkan siswa melakukan berinteraksi, berkreasi dan berkomunikasi dengan menghubungkan panca indera mereka secara antusias sehingga informasi yang masuk ke dalam memorinya lebih tahan lama dan mudah untuk di recall saat informasi itu diperlukan (Arsyad, 2005). Salah satu media dalam pembelajaran adalah media animasi yang dapat mengilustrasikan tahap-tahap perpindahan dari suatu proses (McClean et al., 2005). Animasi dapat membantu pembelajar memahami proses kompleks dan dinamis karena animasi dapat menggantikan konsep abstrak menjadi konkrit (McClean et al., 2005; Lin et al, 2006; O'Day, 2007; O'Day, 2008; Good, 2004). Animasi

memberikan suatu cara efektif untuk menghubungkan istilah dengan komponen, struktur atau proses (O'Day, 2008). Contoh media lainnya adalah media dgmbar

diam, yang dapat menunjukkan representasi visual dari objek-objek yang konkrit maupun abstrak. Gambar dapat terdiri dari ilustrasi, diagram, charta, tabel, peta dan grafik. Morrison dan Tversky (dalam O'Day, 2006) menyatakan bahwa gambar dapat menyampaikan informasi dari konsep yang rumit dengan memperlihatkan komponen-komponen dari sistem konsep yang saling berhubungan satu sama lain. Seluruh komponen dari sistem konsep dapat diperlihatkan secara bersama-sama, memberikan suatu gambaran dari keseluruhan struktur dan setiap kemungkinan hubungan yang ada.

Pembelajaran kooperatif adalah strategi pembelajaran yang di rancang untuk membelajarkan kecakapan akademik (academic skill) sekaligus ketrampilan sosial (social skill) termasuk interpersonal skill (Riyanto, 2008). Menurut Holubec (dalam Nurhadi \& Senduk, 2003) pembelajaran koopertif memerlukan pendekatan pengajaran melalui penggunaan kelompok kecil siswa untuk bekerja sama dalam memaksimalkan kondisi belajar untuk mencapai tujuan belajar. Seperti dalam kebanyakan strategi pembelajaran kooperatif, strategi pembelajaran kooperatif tipe TPS bekerja berdasarkan prinsip siswa bekerja bersama-sama untuk belajar dan bertanggungjawab terhadap belajar temantemannya dalam tim dan juga dirinya sendiri (Handayanto, 2003). Handayanto (2003) juga menyatakan bahwa "pembelajaran kooperatif tipe TPS menekankan berbagai ciri pembelajaran langsung dan merupakan strategi pembelajaran yang mudah diterapkan dalam pembelajaran".

\section{METODE}

Populasi penelitian ini adalah seluruh siswa kelas XI SMAS Mitra Inalum Tahun Pembelajaran 2012/2013 yang berjumlah 240 orang yang terdiri dari 6 kelas. Pengambilan sampel dengan random sampling, karena diambil secara acak sebanyak 3 kelas sebagai kelas yang dikenai perlakuan dari 6 kelas yang ada. Jenis penelitian adalah quasi eksperimen. Rancangan penelitian yang digunakan adalah rancangan eksperimen dengan desain non faktorial. Desain yang digunakan adalah "Pra-tes dan Pasca-tes dengan Kelompok-kelompok yang Diacak" atau Pretest Posttest Control Group Design. Instrumen yang digunakan adalah tes hasil 
belajar dengan bentuk pilihan ganda yang memiliki 5 option pilihan jawaban (a,b,c,d dan e), dan 2 bentuk lagi adalah variasi bentuk soal pilihan ganda yaitu tes dengan bentuk soal hubungan antar hal dan bentuk soal pilihan ganda kompleks. Jumlah soal sebanyak 10 soal setiap sub materi. Tehnik analisis data dilakukan dengan Analisis Covarians (Anacova) dengan bantuan program SPSS SPSS 17.0 (SPSS Inc.).

\section{HASIL}

Sebelum materi diajarkan, siswa dari masing-masing kelas diberikan tes awal untuk mengetahui pengetahuan awal siswa pada materi struktur dan fungsi sel kelas XI SMAS Mitra Inalum. Setelah masingmasing sub materi struktur dan fungsi sel selesai, maka diberikan postes untuk mengetahui hasil belajar siswa. Kemudian setelah 21 hari (3 minggu) sub materi selesai diajarkan, siswa kembali diberikan soal tes dengan tujuan untuk mengetahui retensi (daya ingat) siswa.

Berdasarkan hasil uji normalitas terhadap data retensi dari setiap kelas eksperimen menunjukkan bahwa terdapat sebaran data yang tidak berdistribusi secara normal $(\mathrm{P}<0,05)$. Akan tetapi berdasarkan steam and leaf data menunjukkan bahwa data masih dianggap berdistribusi normal sehingga pengujian hipotesis masih dapat diterapkan. Hal ini diperkuat oleh pernyataan Jerrold (1987) yang menyatakan bahwa analisis varians bersifat robust (handal) sejauh kelompok yang dibandingkan memiliki jumlah yang sama atau hampir sama. Selanjutnya, Jerrold (1987) juga menyatakan bahwa analisis varians juga bersifat robust (handal) terhadap asumsi normalitas populasi. Sementara itu hasil uji homogenitas data skor retensi siswa dengan nilai sig. 0,132 > 0,05 . Dengan demikian, dapat disimpulkan bahwa varians data retensi homogen (sama).

Deskripsi data mengenai retensi memori siswa berisi gambaran skor total retensi siswa pada kelas yang dibelajarkan dengan strategi pembelajaran kooperatif tipe TPS dengan media animasi, pada kelas yang dibelajarkan dengan strategi pembelajaran kooperatif tipe TPS dengan media gambar diam, dan pada kelas yang dibelajarkan dengan strategi pembelajaran konvensional masing-masing sebesar $24,75 \pm 0,38,24,90 \pm 0,33$, dan 23,38 $\pm 0,26$. Hal ini menjelaskan retensi siswa dari kelas yang dibelajarkan dengan strategi pembelajaran kooperatif tipe TPS dengan media gambar diam animasi lebih tinggi dari kelas yang dibelajarkan dengan strategi pembelajaran kooperatif tipe TPS dengan media animasi, dan pada kelas yang dibelajarkan dengan strategi pembelajaran konvensional.

Tabel 1. Rata-rata Retensi Siswa pada Setiap Sub Materi

\begin{tabular}{lccc}
\hline \multirow{2}{*}{ Materi } & \multicolumn{3}{c}{ Retensi } \\
\cline { 2 - 4 } & $\begin{array}{c}\text { Kelas TPS + } \\
\text { Animasi }\end{array}$ & $\begin{array}{c}\text { Kelas TPS + } \\
\text { Gambar Diam }\end{array}$ & $\begin{array}{c}\text { Kelas } \\
\text { Konvensional }\end{array}$ \\
\hline Sel dan fungsinya & $5,40 \pm 0,12$ & $5,00 \pm 0,11$ & $4,63 \pm 0,12$ \\
Struktur dan fungsi sel hewan & $5,30 \pm 0,13$ & $5,10 \pm 0,11$ & $4,68 \pm 0,09$ \\
Struktur dan fungsi sel tumbuhan & $4,75 \pm 0,17$ & $5,00 \pm 0,14$ & $4,80 \pm 0,13$ \\
Perbedaan sel hewan dan tumbuhan & $4,38 \pm 0,13$ & $4,53 \pm 0,11$ & $4,80 \pm 0,13$ \\
\hline
\end{tabular}

Berdasarkan hasil uji hipotesis untuk skor retensi secara keseluruhan diperoleh nilai sig. $0,03<0,05$. Hal ini berarti hipotesis null ditolak atau diterima hipotesis kedua yang menyatakan terdapat perbedaan retensi memori siswa kelas XI SMAS Mitra Inalum yang dibelajarkan menggunakan strategi pembelajaran kooperatif tipe TPS melalui media animasi, strategi pembelajaran kooperatif tipe TPS melalui media gambar diam dan strategi pembelajaran konvensional. Hasil uji lanjut dengan Parameter Estimates terlihat bahwa retensi memori siswa yang paling baik 
adalah dengan penggunaan strategi pembelajaran kooperatif tipe TPS melalui media gambar diam selanjutnya disusul oleh strategi pembelajaran kooperatif tipe TPS menggunakan media animasi dan disusul oleh strategi pembelajaran konvensional.

Hasil analisis skor retensi pada setiap sub materi dimulai dari materi Struktur dan Fungsi Sel diperoleh nilai sig. 0,000 $<0,05$. Dengan demikian terdapat perbedaan retensi memori siswa kelas XI SMAS Mitra Inalum pada sub materi Struktur dan Fungsi Sel dari kelas yang dibelajarkan dengan menggunakan strategi pembelajaran kooperatif tipe TPS melalui media animasi, strategi pembelajaran kooperatif tipe TPS melalui media gambar diam dan strategi pembelajaran konvensional. Hasil uji lanjut dengan Parameter Estimates terlihat bahwa retensi memori siswa yang paling baik pada sub materi Struktur dan Fungsi Sel adalah dengan penggunaan strategi pembelajaran kooperatif tipe TPS melalui media animasi selanjutnya disusul oleh strategi pembelajaran kooperatif tipe TPS menggunakan media gambar diam dan disusul oleh strategi pembelajaran konvensional.

Hasil analisis skor retensi pada setiap materi Sel diperoleh nilai sig. . 0,450 > 0,05 . Dengan demikian tidak terdapat perbedaan retensi memori siswa kelas XI SMAS Mitra Inalum pada materi Sel dari kelas yang dibelajarkan dengan menggunakan strategi pembelajaran kooperatif tipe TPS melalui media animasi, strategi pembelajaran kooperatif tipe TPS melalui media gambar diam dan strategi pembelajaran konvensional.

\section{PEMBAHASAN}

Berdasarkan hasil analisis pada penelitian ini terlihat bahwa retensi siswa lebih tinggi pada kelas yang diajar dengan strategi pembelajaran kooperatif dengan media gambar diam. Hal ini tidak sesuai dengan O'Day (2007) mengungkapkan bahwa animasi memberikan retensi ingatan jangka panjang yang lebih baik daripada gambar diam. Durasi dari penayangan media mempengaruhi konsentrasi siswa dalam memahami maksud dari informasi yang disampaikan. Hal ini sejalan dengan O'Day (2006) yang menyatakan bahwa gambar dapat mempermudah pemahaman. Belajar, mengingat dan menarik kesimpulan dari informasi yang disajikan. Pembelajaran kooperatif tipe TPS menggunakan media gambar diam dapat meningkatkan pemahaman siswa akan sejumlah informasi yang bersifat abstrak. O'Day (2006) menyatakan bahwa gambar dapat menyampaikan informasi dari konsep yang rumit dengan memperlihatkan komponenkomponen dari sistem konsep yang saling berhubungan satu sama lain. Sementara pembelajaran konvensional tanpa difasilitasi media pembelajaran lebih bersifat teoritis dan abstrak sehingga kemampuan diperoleh hanya melalui latihan dan tanya jawab sehingga berpengaruh kepada kemampuan encoding, storage, dan, retrieval dari sejumlah informasi yang telah diberikan.

Berdasarkan hasil analisis uji lanjut dari empat sub materi, terlihat bahwa materi Struktur dan Fungsi Jaringan Tumbuhan serta sub materi Struktur Organ Tumbuhan lebih baik retensi siswanya apabila diajarkan dengan strategi pembelajaran kooperatif tipe TPS dengan media animasi, disusul dengan TPS dengan media gambar diam, dan disusul dengan strategi konvensional. Sub materi Kultur Jaringan dan Struktur dan Fungsi Jaringan terlihat tidak ada perbedaan strategi manakah yang terbaik, hal ini disebabkan karena tingkat kesulitan materi dan ketidaksesuaian dalam pemilihan strategi serta media. Media yang digunakan sebagai alat bantu penyampai informasi masih memiliki banyak kelemahan-kelemahan sehingga tidak dapat mewakili seluruh informasi yang semestinya diberikan kepada siswa. Sementara sub materi Organ Sistem Organ terlihat bahwa strategi pembelajaran kooperatif tipe TPS menggunakan gambar diam lebih baik dari dua strategi lainnya. 


\section{KESIMPULAN}

Strategi pembelajaran yang terbaik untuk memperoleh retensi memori siswa adalah strategi pembelajaran kooperatf tipe TPS menggunakan media gambar diam, disusul dengan strategi pembelajaran kooperatf tipe TPS menggunakan media animasi, dan disusul strategi pembelajaran konvensional. Hasil analisis tingkat sub materi menjelaskan bahwa strategi terbaik untuk sub materi Struktur dan Fungsi Jaringan Tumbuhan serta sub materi Struktur Organ Tumbuhan adalah strategi pembelajaran kooperatif tipe TPS dengan media animasi, disusul dengan TPS dengan media gambar diam, dan disusul dengan strategi konvensional. Untuk sub materi Kultur Jaringan dan Struktur dan Fungsi Jaringan terlihat tidak ada perbedaan strategi manakan yang terbaik. Sementara strategi pembelajaran terbaik untuk sub materi Organ Sistem Organ terlihat adalah strategi pembelajaran kooperatif tipe TPS menggunakan media gambar diam, disusul strategi pembelajaran kooperatif tipe TPS menggunakan media animasi, dan disusul dengan strategi konvensional.

\section{DAFTAR RUJUKAN}

Arsyad. 2005. Media Pembelajaran. Rajawali Press Indonesia. Jakarta.

Armstrong, N., Chang \& Brickman. 2007. Cooperative Learning in Industrial-sized Biology Classes. CBE-Life Sciences Education. 6:163171.

Good, D. J. 2004. The use flash animation within a web environment, enhancing comprehension of experimental procedures in biotechnology laboratory, International Journal of Intructional Media. Volume 4:355-371.

Handayanto, S. K. 2003. Strategi pembelajaran Fisika. FMIPA UM. Malang

Jerrold, H, Zar. 1984. Biostatistical Analysis (Second Edition). Prentice-Hall, Inc. Englewood cliffs, New Jersey.

Koroghlanian, D., Klein, J.D. 2004. The effect of audio and animation in multimedia instruction. Journal of Educational Multimedia and Hypermedia, 13: 23-46.

Kartolo, A. 2010. Pembelajaran Kooperatif Model TPS Dan TGT Ditinjau Dari Aktivitas Belajar dan Kemampuan Awal Siswa. (Studi Kasus
Pada Mata Pelajaran IPA Pokok Materi Sistem Ekskresi Manusia Kelas IX di SMP Negeri 2 Wonogiri. Program Studi Pendidikan Sains. Sekolah Pascasarjana Universitas Sebelas Maret. Surakarta.

Lin, H., Chen, T.,Dywer, F. M. 2006. Effect of static visuals and computer generated animations in facilitating immediate and delated achiecvement in etl classroom. Foreign Langguage Annals, 2:203-219.

Matlin, M.W. 1984. Cognition. Fort Worth:Harcourt Brace Publishers.

Morrison, J. B. dan Tversky, B.2001. The (In) Effectiveness of animation:short talks. CHI.

Marpaung. 2001. Pendekatan Kontekstual Dan Sains Dalam Pembelajaran Matematika. Disampaikan dalam Seminar RME di USD Yogyakarta, 14-15 Nopember 2001.

McClean, P., Johnson, C., Rogers, R., Daniels, L., Reber, J., Slator, B. M., Terpstra, J., and White, A. 2005. Molecular and cellular biology animations: development and impact on student learning. Cell Biol. Education. 4: 169-179.

Nurhadi \& Senduk, G. A. 2003. Pembelajaran Kontekstual dan Penerapannya Dalam KBK. Universitas Negeri Malang.

O'Day, D. H. 2006. Animated cell biology: a quick and easy method for making effective high-quality teaching animations. CBE Life Science Education, 5: 255-263.

O'Day, D. H. 2007. The value of animation in biology teaching : a study of long term memory retention. CBE Life Science Education, 6: 217-223.

O'Day, D. H. 2008. Using animation to teach biology: past and future research on the attributes that underline pedagogically sound animation.The American Biology Teacher, 5:274-278.

Paivio, A. 1991. Dual coding theory: retrospect and current status. Canadian Journal Psychology, $45,255-287$.

Prayitno \& Manullang, B. 2010. Pendidikan Karakter dalam Pembangunan Bangsa. Pascasarjana Universitas Negeri Medan.

Rieber, L. P. 1990. Using Animation in Science Instruction with Young Children. Journal Of Educational Pshychology. Vol 82, hal. 135140.

Riyanto,Y. 2008. Paradigma Baru Pembelajaran Sebagai Referensi bagi Pendidik dalam Implementasi Pembelajaran yang Efektif dan berkualitas. Kencana Prenada Media Group. Jakarta. 
Irwansyah / Jurnal Pendidikan Biologi 7 (1) (2017) 1-8

Sanjaya.,W. 2008. Strategi Pembelajaran Berorientasi Standar Proses Pendidikan. Edisi pertama.Cetakan ke-5. Kencana.
Wirahayu. A.Y.\& Kristianto.S.M. 2007. Peningkatan Pemahaman Geografi dengan Strategi Pembelajaran Berbasis Masalah. Jurnal Penelitian Pendidikan. Tahun 17(1). 